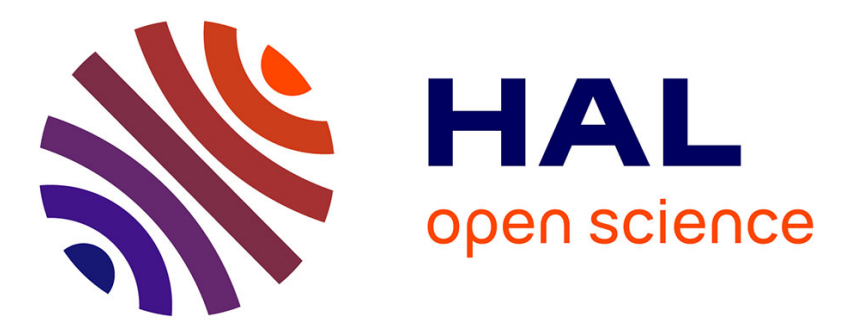

\title{
Relationship Between Martensite Islands and Haz Fracture Toughness in Welded Ni-Cu Structural Steels
}

\author{
R. Ranade, F. Barbaro, J. Williams, P. Munroe, P. Krauklis
}

\section{To cite this version:}

R. Ranade, F. Barbaro, J. Williams, P. Munroe, P. Krauklis. Relationship Between Martensite Islands and Haz Fracture Toughness in Welded Ni-Cu Structural Steels. Journal de Physique IV Proceedings, 1995, 05 (C8), pp.C8-311-C8-316. 10.1051/jp4:1995844 . jpa-00254093

\section{HAL Id: jpa-00254093 https://hal.science/jpa-00254093}

Submitted on 1 Jan 1995

HAL is a multi-disciplinary open access archive for the deposit and dissemination of scientific research documents, whether they are published or not. The documents may come from teaching and research institutions in France or abroad, or from public or private research centers.
L'archive ouverte pluridisciplinaire $\mathbf{H A L}$, est destinée au dépôt et à la diffusion de documents scientifiques de niveau recherche, publiés ou non, émanant des établissements d'enseignement et de recherche français ou étrangers, des laboratoires publics ou privés. 


\title{
Relationship Between Martensite Islands and Haz Fracture Toughness in Welded Ni-Cu Structural Steels
}

\author{
R.S. Ranade, F.J. Barbaro*, J.G. Williams*, P.R. Munroe and P. Krauklis \\ School of Materials Science and Engineering, UNSW, Sydney, NSW 2052, Australia \\ * BHP Slab and Plate Products Division, PO. Box 1854, Wollongong, NSW 2500, Australia
}

\begin{abstract}
The relationship between high carbon martensite island constituent $\left(M^{*}\right)$ and the HAZ CTOD fracture toughness has been evaluated in four HSLA plate steels containing varying amounts of $\mathrm{C}, \mathrm{Ni}$ and $\mathrm{Cu}$. Test pieces with plane fusion boundaries were made by first pass welding and then $\mathbf{M}^{*}$ constituent was produced by thermal simulation of second pass welding, intercritically reheating the HAZ to $1043 \mathrm{~K}$. $\mathrm{M}^{*}$ was evaluated by quantitative light microscopy and the CTOD fracture toughness was measured in the coarse-grained region of the $\mathrm{HAZ}$. The volume fraction of $\mathrm{M}^{*}$ increases with the carbon content of the steel, and also with the combined content of nickel and copper, but the latter occurs at a much lower rate. The amount of $\mathbf{M}^{*}$ does not correlate well with the IIW carbon equivalent, being lower than expected at high $\mathrm{Ni}$ and $\mathrm{Cu}$ contents. The CTOD fracture toughness decreases with increasing volume fraction of $\mathbf{M}^{*}$. The weldability of steels containing nickel and copper is significantly better than indicated by hardenability based formulae, such as IIW $\mathrm{C}_{\mathrm{eq}}$.
\end{abstract}

\section{INTRODUCTION}

Microalloying and thermomechanical controlled processing (TMCP) enable higher strength, toughness and weldability to be produced in plate steels at lower carbon equivalents $\left(C_{e q}\right)$ than is possible with $\mathrm{C}-\mathrm{Mn}$ steels [1]. Such high-strength low-alloy (HSLA) steels containing $\mathrm{Ni}$ and $\mathrm{Cu}$ are used in offshore platforms and other large structures which require good heat affected zone (HAZ) toughness in multiple-pass welds. An important welding design parameter is the HAZ fracture toughness, which is sensitive to microstructure, and may be assessed by the crack tip opening displacement (CTOD) of a sharp crack located in the HAZ.

In multiple-pass welding of HSLA steel the HAZ exhibits a variety of microstructures which are related in a complex manner to both the steel chemistry and the thermal cycles produced by successive welding passes $[1,2]$. During the first welding pass, austenite coarsening near the fusion boundary creates a coarse-grained region (CGHAZ) which on cooling transforms to a ferritic-bainitic microstructure, which may contain a small amount of residual austenite enriched with carbon and high carbon martensite islands $\left(M^{*}\right)$. The microstructure that develops during the thermal cycles produced by subsequent welding passes depends on the peak temperatures and cooling rates achieved in different parts of the original CGHAZ. In those areas of the CGHAZ that experience complete reaustenitisation, a microstructure similar to the original CGHAZ is re-created on cooling. In areas that experience intercritical reheating of the coarse-grained region (IRCGHAZ), partial re-austenitisation occurs, not only at the original carbon-rich areas, but also at prior austenite grain boundaries, due to rapid boundary diffusion. The latter austenite may form additional martensite islands in a necklace distribution on cooling. In areas that are sub-critically reheated, martensite islands are modified by tempering $[3,4]$.

The occurrence of coarsened structures containing an unfavourable distribution of $\mathbf{M}^{*}$ can lcad to reduced fracture toughness in local brittle zones (LBZ's) within the IRCGHAZ. The reduction in 
fracture toughness is associated with increasing fracture facet size and the presence of $M^{*}$ [5]. The $\mathbf{M}^{*}$ may occur as elongated intra-lath constituent $[4,6]$, a network of more equiaxed islands at prior austenite grain boundaries $[2,4,6,7]$, and at pro-eutectoid ferrite boundaries [6]. The adverse effect of $\mathbf{M}^{*}$ on toughness depends on the volume fraction, size and distribution of $\mathbf{M}^{*}$, and has been attributed to various phenomena associated with the hard martensite islands including microcracking, increased residual stress and stress concentration [7].

The results reported in this paper are the first part of an investigation of the formation of $\mathbf{M}^{*}$ in the IRCGHAZ of four microalloyed HSLA steels with small variations in $\mathrm{C}, \mathrm{Cu}$ and Ni content, aimed at finding what correlations exist between steel composition, $\mathbf{M}^{*}$ characteristics and fracture toughness.

\section{EXPERIMENTAL MATERIALS AND PROCEDURES}

The compositions of the four steels studied are given in weight percent in the table below. They are $\mathrm{Nb}-\mathrm{Ti}$ microalloyed steels produced by thermomechanical controlled processing. They have small variations in carbon, nickel and copper content, and were designated as high (H), medium (M) or low (L) with respect to carbon content (C) and combined nickel and copper alloy content (A); eg LCHA refers to low carbon, high alloy content within the scope of this work.

\begin{tabular}{|l|l|l|l|l|l|l|l|l|l|l|l|l|l||}
\hline Steel & $\mathrm{C}$ & $\mathrm{P}$ & $\mathrm{Mn}$ & $\mathrm{Si}$ & $\mathrm{S}$ & $\mathrm{Ni}$ & $\mathrm{Cr}$ & $\mathrm{Mo}$ & $\mathrm{Ca}$ & $\mathrm{Al}$ & $\mathrm{Nb}$ & $\mathrm{Ti}$ & $\mathrm{V}$ \\
\hline \hline MCLA & .06 & .015 & 1.42 & .27 & .005 & .20 & .034 & .004 & .19 & .016 & .018 & .008 & .003 \\
\hline HCLA & .085 & .016 & 1.51 & .30 & .005 & .22 & .03 & .005 & .19 & .051 & .019 & .013 & .003 \\
\hline HCMA & .075 & .015 & 1.42 & .28 & .004 & .45 & .021 & .006 & .27 & .025 & .023 & .016 & .003 \\
\hline LCHA & .045 & .012 & 1.43 & .29 & .004 & .79 & .019 & .004 & 1.05 & .028 & .019 & .013 & .004 \\
\hline
\end{tabular}

The plates, which were originally between 12 and $40 \mathrm{~mm}$ thick, were machined to a uniform $12 \mathrm{~mm}$ thickness. $1 \mathrm{~m}$ long coupons of each material were submerged arc welded (SAW) with a heat input of $3 \mathrm{kJmm}^{-1}$. Samples $21 \times 11 \times 150 \mathrm{~mm}$ were then machined from these welds in the transverse direction and reheated in the HAZ to thermally simulate a second weld pass [8]. The samples were reheated at a rate of $200 \mathrm{Ks}^{-1}$ to $1043 \mathrm{~K}$ and immediately cooled at a constant rate of $3.3 \mathrm{Ks}^{-1}\left(\Delta \mathrm{t}_{8-5}=\right.$ $90 \mathrm{~s}$ ). The intercritical reheating temperature was selected to create microstructures with networked martensite islands, similar to those in actual welded structures.

Metallographic specimens were then prepared from the IRCGHAZ and etched in $2 \%$ nital solution for general examination. Characterisation of $M^{*}$ was conducted on a minimum of 20 fields by light microscopy. For this purpose, the contrast between $M^{*}$ and rest of the matrix was enhanced by using a modified LePera etching technique [9]. The volume fraction of $\mathbf{M}^{*}$ was estimated using image analysis software developed by the CSIRO Division of Mathematics and Statistics, which was validated by manual point counting to ASTM E-563. The compositions of $\mathbf{M}^{*}$ and matrix regions were compared by electron microprobe wavelength dispersive spectroscopy (WDS).

To prepare CTOD test pieces the samples were etched in $10 \%$ nital to clearly delineate the weld metal, HAZ and parent plate regions. The fusion line was marked, and a notch was cut with a 0.38 mm slitting blade as close as possible, and parallel to, the fusion boundary in the CGHAZ region. A through-thickness fatigue pre-crack was then generated from the root of the notch so as to lie entirely in the microstructure of interest, generally within $0.3 \mathrm{~mm}$ of the fusion boundary. 
CTOD measurements were carried out in accordance with AS 2205.7.3-1983 on two or three identical samples. To validate each CTOD test, the fractured sample was sectioned and examined metallographically, and the distance between the fusion line and fracture plane was measured with a low power microscope. The condition for the test to be valid is that the fatigue notch must intersect a minimum of $15 \%$ coarse-grained $\mathrm{HAZ}$ in the mid $50 \%$ of the specimen thickness, which is in accordance with the testing criteria for offshore platform steels of EEMUA 1986 [10]. The lowest of the valid results was used as the CTOD value.

\section{RESULTS AND DISCUSSION}

Micrographs of the CGHAZ and IRCGHAZ of two of the four steels are shown in figures 1a to d. The as-welded microstructures consist mainly of grain boundary ferrite and ferrite with aligned martensite-austenite-carbide (MAC), the latter also commonly referred to as upper bainite. The IRCGHAZ microstructures are essentially similar to the as-welded structures except for additional blocky martensite islands formed at prior austenite grain boundaries. Similar microstructures have been observed by other researchers $[11,12]$.

Figures $1 \mathrm{e}$ and $\mathrm{f}$ show the IRCGHAZ microstructures etched in modified LePera etchant. This etchant improves quantitative estimation of $\mathbf{M}^{*}$ volume fraction by enhancing contrast between the matrix and the $\mathrm{M}^{*}$ which facilitates image analysis. Two stage electrolytic etching and deep etching in $4 \%$ nital has also been used to observe $M^{*}$ in the scanning electron microscope (SEM) by other investigators $[4,6]$. However, the modified LePera etchant provides a more consistent and accurate method of $\mathbf{M}^{*}$ estimation [9]. WDS analysis revealed the carbon content of the $\mathrm{M}^{*}$ islands to be $0.8-1.0 \%$ above the matrix value, while the nickel and copper contents of the $M^{*}$ islands and matrix were found to be the same.

Figure 2 shows the variation of $\mathrm{M}^{*}$ volume fraction in the IRCGHAZ with carbon content, and it is evident that the volume fraction of $\mathrm{M}^{*}$ increases with carbon content in steels MCLA, HCMA and HCLA. However, the observed increases can not be attributed solely to carbon, since the content of alloying elements also varies between the steels, particularly nickel and copper. The effects of individual elements cannot be isolated with the compositions available, but the combined effect of nickel and copper can be equated to the effect of carbon by comparing steels LCHA and MCLA, which have the same volume fraction of $M^{*}$, and assuming that effects due to differences in the other elements are neglible. On this basis, the same change in volume fraction of $M^{*}$ is produced by the difference in carbon contents of $0.015 \%$, as is produced by the difference in combined nickel and copper contents, of $1.45 \%$. Thus, carbon appears to be about 100 times more potent in increasing volume fraction of $\mathbf{M}^{*}$ than combined copper and nickel additions.

Figure 3 shows the variation of $\mathbf{M}^{*}$ volume fraction in the IRCGHAZ with the International Institute of Welding carbon equivalent, $C_{e a}$, commonly used to assess weldability. The volume fraction of $M^{*}$ increases with $\mathrm{C}_{\mathrm{eq}}$ in steels MCLA, HCMA and HCLA, but drops to a low value at the highest $\mathrm{C}_{\mathrm{eq}}$ for steel LCHA. The lower amount of $\mathbf{M}^{*}$ in this steel is due to its low carbon and high $\mathrm{Ni}$ and $\mathrm{Cu}$ contents, and is in agreement with other work indicating that substitution of carbon with nickel and copper reduces the amount of $M^{*}$ [13]. The poor correlation between volume fraction of $M^{*}$ and $C_{e q}$ is due to the coefficient, $1 / 15$, used to convert combined copper and nickel content to equivalent carbon in the $\mathrm{C}_{\mathrm{eq}}$ formula. This is based on early hardenability data, and clearly does not reflect the actual effect of these elements in increasing the amount $\mathbf{M}^{*}$, which is smaller by a factor of about 6 .

Figure 3 also shows that the amount of large martensite islands, over $1 \mu \mathrm{m}^{2}$ in area, is significantly greater in the two steels with high carbon content, HCMA and HCLA, compared with the other two steels which contain almost no large $\mathrm{M}^{*}$. It was observed also that an increase in $\mathrm{Cu}$ and $\mathrm{Ni}$ concentrations produces relatively more equiaxed $\mathrm{M}^{*}$. 
Figure 4 shows CTOD values for tests done at three temperatures. The CTOD values decrease as temperature is reduced in all cases. It is evident also that the temperatures for $0.4 \mathrm{~mm}$ CTOD increase in the order LCHA, MCLA, HCMA and HCLA, which corresponds exactly with increasing $\mathbf{M}^{*}$ volume fraction, figure 3 . This is true for both the total volume fraction of $\mathbf{M}^{*}$ and for the volume fraction of $\mathrm{M}^{*}$ islands greater than $1 \mu \mathrm{m}^{2}$ in area. It has been proposed that only the larger islands are significant in reducing fracture toughness $[4,7]$, and this appears to be confirmed by the present work. It may be seen in figure 3 that steels HCMA and HCLA with the highest carbon contents have the highest volume fractions of large $\mathrm{M}^{*}$ islands, and in figure 4 these also have the lowest CTOD values at all test temperatures. On the other hand, steels LCHA and MCLA which have almost no large $\mathrm{M}^{*}$ have significantly better fracture toughness.

\section{CONCLUSIONS}

The following conclusions were reached for IRCGHAZ structures in welded HSLA steels containing nickel and copper.

1. The martensite island volume fraction increases with carbon content. It also increases with nickel and copper content, but at a much lower rate, about 1/100, compared with carbon content.

2. The martensite island volume fraction does not correlate well with IIW carbon equivalent, $C_{e q}$, increasing with $\mathrm{C}_{\mathrm{eq}}$ at lower nickel and copper contents, but being lower than expected at higher copper and nickel contents.

3. Increasing the copper and nickel content causes an increase in the proportion of equiaxed martensite islands.

4. The CTOD fracture toughness of the IRCGHAZ decreases as the volume fraction of martensite islands increases, particularly for larger islands over $1 \mu \mathrm{m}^{2}$ in area.

5. Weldability in the presence of nickel and copper is significantly better than indicated by hardenability based formulae, such as $\mathrm{C}_{\mathrm{eq}}$.

\section{Acknowledgments}

The authors wish to thank Dr. Ed Breen (CSIRO Division of Mathematics and Statistics Sydney) for image analysis computation, Messrs. Geoff Thompson and Heiko Tysar (BHP SPPD Port Kembla) for assistance with the fracture toughness testing, and Dr. Brian Gleeson (UNSW Sydney) for helpful discussions. The financial support of the Australian Research Council with grant number A89131558 is gratefully acknowledged.

\section{References}

[1] Haze T. et al., Nippon Steel Technical Report, No.36, (Jan 1988).

[2] Okamoto K. et al., Pacrim Weldcon '92, Darwin, 29 June - 3 July 1992, (WTIA, Sydney, 1992), paper23.

[3] Matsuda F. et al., Welding in the World, 29(9/10), (1991).

[4] Hrivnak I., Matsuda F. and Ikeuchi K., Trans. of JWRI, 21(2), (1992), 9-31.

[5] Fukuda Y. and Komizo Y., Trans. of JWRI, 23(2), (1992), 31-38.

[6] Lee S., Kim B.C. and Kwon D., Metall. Trans. A, 23A, (1992), 2803-2816.

[7] Davis C.L. and King J.E., Metall. and Mater. Trans. A, 25A, (1994), 563-573.

[8] Thompson G., Smith D. and Barbaro F.J., BHP SPPD report No. PK/TIC/93/033.

[9] Ranade R. et al., "Metallographic Assessment of Martensite Island Constituent in Welded Structural Steels", conf. on Microscopy: Materials and Techniques, Sydney, 21-22 Sept. 1993, (IMMA, Melbourne, 1993) pp. 49-54.

[10] Barbaro F.J., PhD Thesis, UNSW, 1989.

[11] Lee S., Kim B.C. and Kwon D., Metall. Trans. A, 24A, (1993), 1133-1141.

[12] Ahmed N.U. and Yellup J.M., Materials Forum, 12, (1988), 62-72.

[13] Lee J. and Pan Y., Metall. Trans. A, 24A, (1993), 1399-1408. 
C8-315
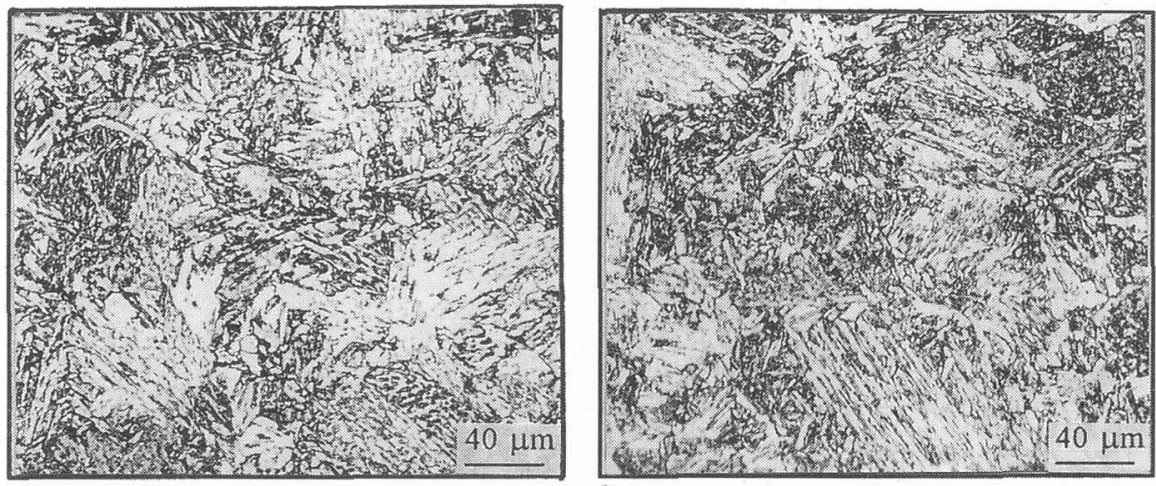

b
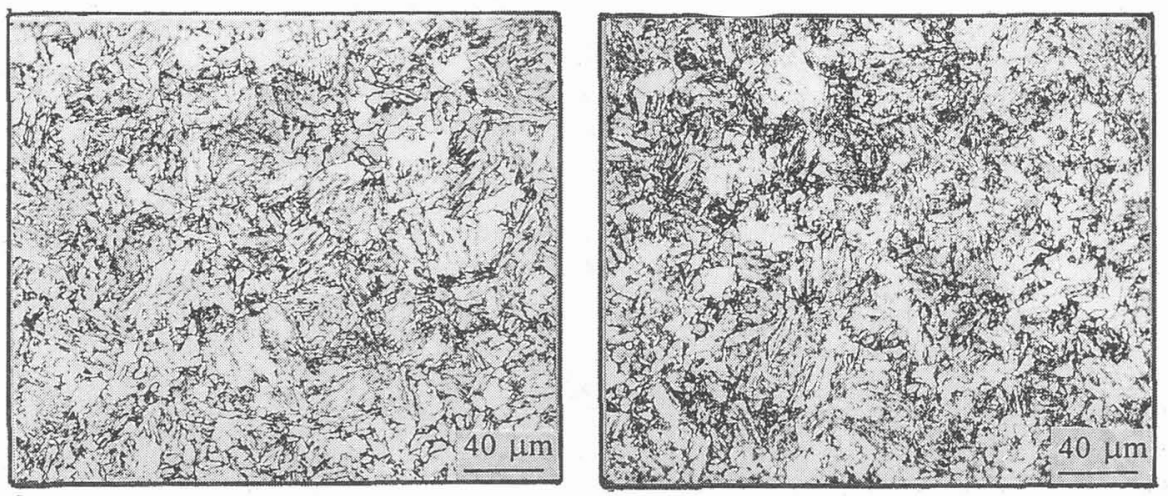
$\mathrm{c}$

$$
\text { d }
$$
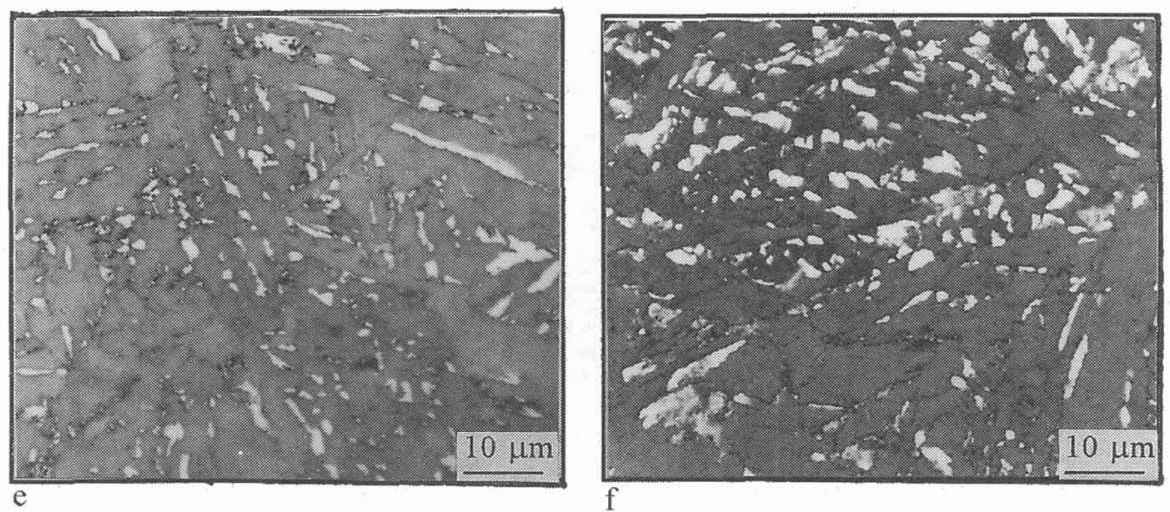

Fig.1 : Microstructures of as-welded CGHAZ and IRCGHAZ steels; a) MCLA as-welded; b) HCLA as-weided; c) MCLA IRCGHAZ; d) HCLA IRCGHAZ; a) to d) etched in $2 \%$ nital. e) and f) same as c) and d) respectively, but etched in modified LePera etchant. The microstructures of LCHA and HCMA are similar to MCLA and HCLA respectively. 


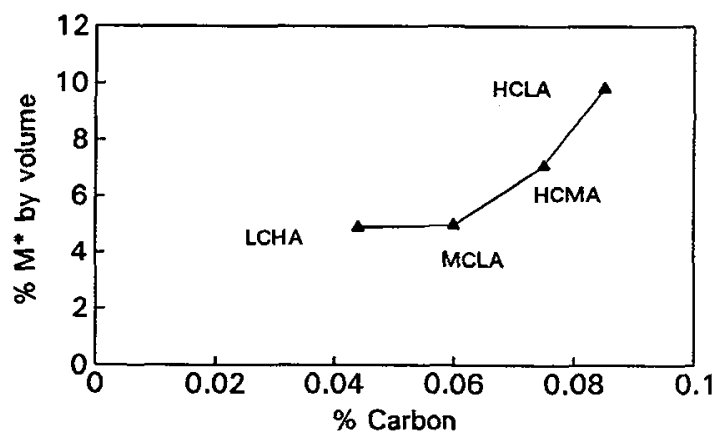

Fig. 2 Variation of $M^{*}$ volume fraction with carbon content

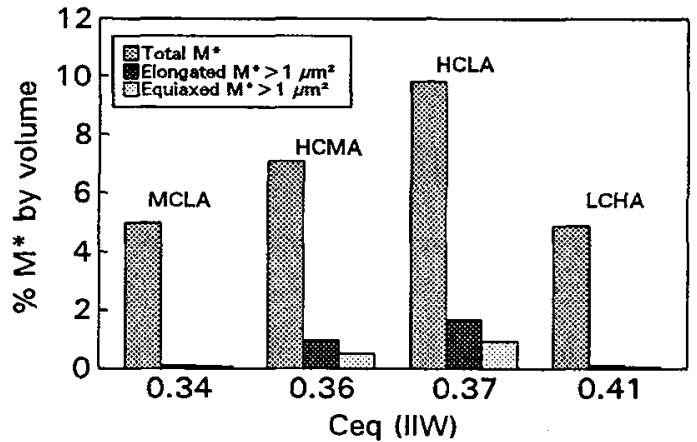

Fig.3 Variation of $M^{*}$ volume fraction with carbon equivalent (Ceq)

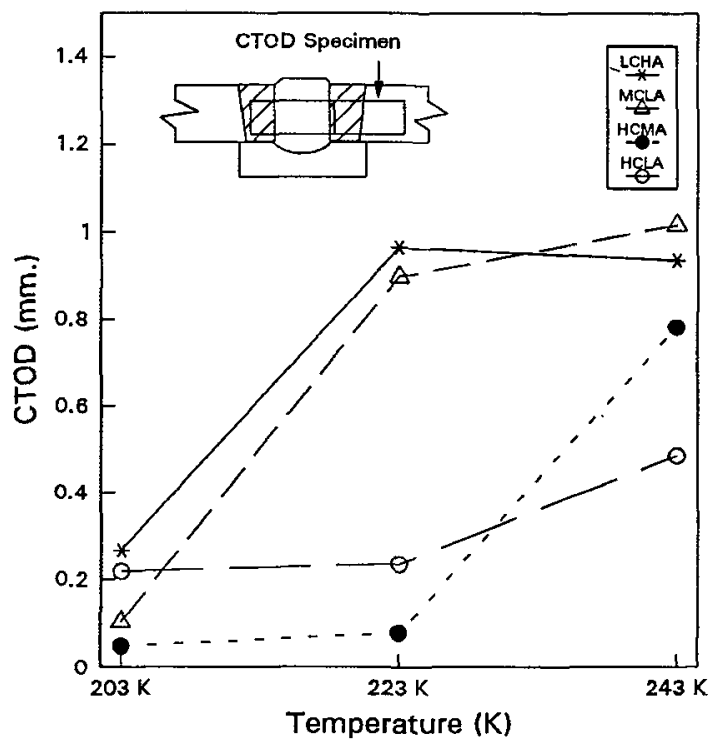

Fig.4 CTOD values at three different temperatures 